\title{
Environmental Management of the Inle Lake in Myanmar
}

Zaw Lwin and M.P. Sharma

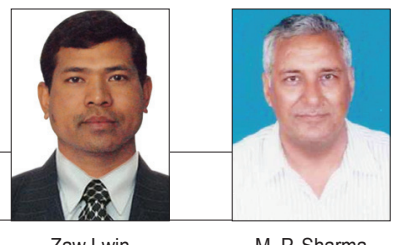

Abstract: The Inle Lake, the second-largest lake in Myanmar, is located in Shan State in Myanmar. More than 170,000 people inhabit the lake and its surroundings, and their main business is agriculture with the floating gardens. Due to its picturesque siting and diverse fauna, combined with the unique lifestyles and traditions of human inhabitants, the lake is considered as one of the primary tourist destinations in Myanmar. The Inle is not only designated as the 190th World's Eco-region but also nominated as one of the fresh water biodiversity hotspots. Since the last decade, the lake has been facing serious threats due to natural and man-made pressure leading to the deterioration of its water quality and shrinkage of the open water area. According to the assessment of its water quality in 2012, the trophic state index of the Inle Lake is found to be in the range of eutrophication.

The present paper aims to identify the problems based on data collected from the lake authorities and prepare a management plan for its conservation. The estimated cost is 31.18 million US\$ and is expected to improve the lake health significantly, if the conservation plan is implemented by the government in the true sense.

Key words: Trophic State Index (TSI), eutrophication, environmental management, water quality, Myanmar

\section{Introduction}

Water is the most important resource being exploited by humans more than any other resource for the sustenance of life. As per an estimate, more than half of the world's population is likely to face water shortage as the water demand will exceed the supply by $50 \%$ by 2025 as studied by Cooke et al, 2005 . The problem is becoming serious due to rapid population

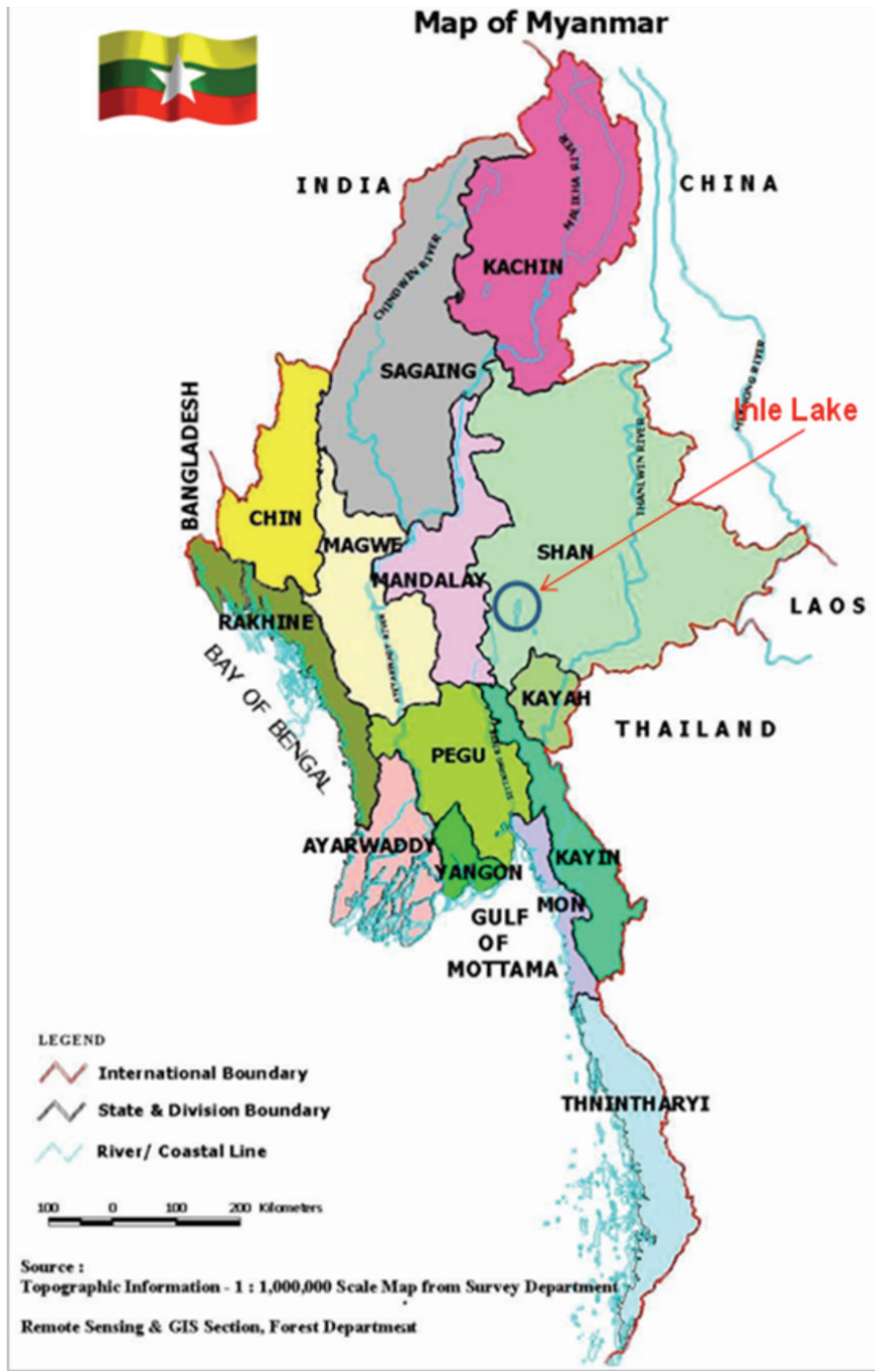

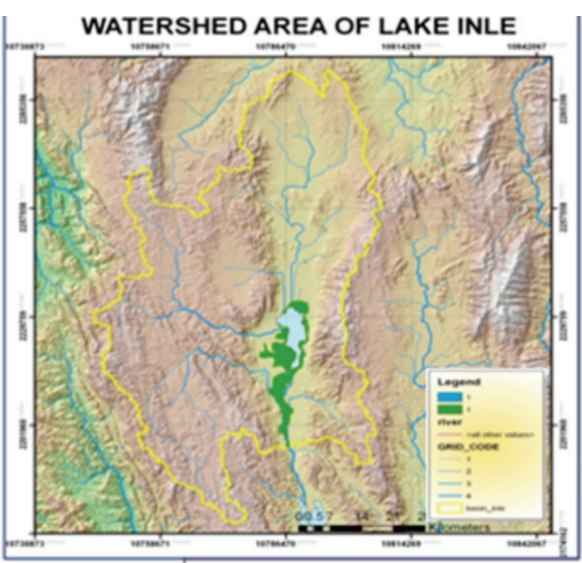

Inle Lake' 2012 Water Sample Loc ation Map

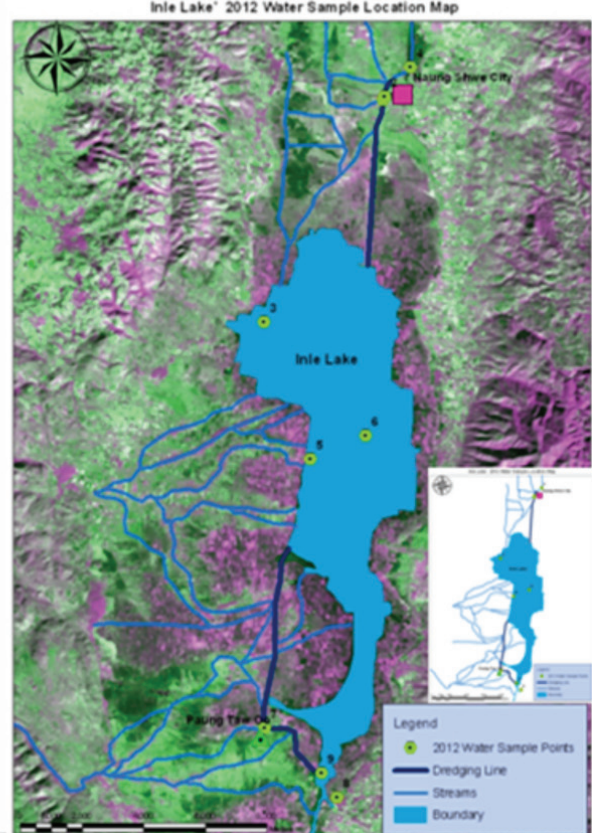

Figure 1. The Inle Lake in Myanmar. 
growth, rapid urbanization and industrialization resulting in huge water shortages. The water demands are met from the fresh water resources like rivers, lakes, ponds, streams and ground water. As a result, these water resources are becoming subject to heavy pollution making most of water unfit for human consumption as no efforts are made to treat waste water and reuse the treated water. Lakes are important landscape, which are not only the source of precious water, but also provide valuable habitats to plants and animals, moderate hydrological cycles, influence microclimate, enhance the aesthetic beauty of the landscape and provide recreational opportunities to humankind. Sharma (2010) found that the lakes are also used for meeting drinking, irrigation water, fishing, eco-tourism demands etc. The lakes suffer from numerous problems owing to increasing anthropogenic activities in the catchment. These problems include lake shrinkage, shoreline erosion, deteriorating water quality, biodiversity, changes in Lake Hydrology and climatic regimes. In view of the deteriorating lake health, it becomes necessary to restore and manage the lakes environmentally by employing suitable restoration technologies that may help bring about the improvement in lake health as found in the NRCD Report, 2010.

The present paper attempts to identify problems of the Inle Lake in Myanmar using the data collected on various activities in the lake catchment, quantify the problems and identify the major stressors. The technologies suitable for environmental management of the Inle lake are suggested along with the preparation of a management plan including cost analysis of the technology suggested as well as the O\&M cost together with the expected benefits. The brief details of conservation works already underway are also given in the paper.

\section{About Inle Lake}

The Inle Lake, the second largest lake of Myanmar, is situated in Shan State in the Northeastern side of the country. The Inle catchment includes the watershed of Taunggyi, Nyaung Shwe, Yaksauk, Pindaya, Kalaw, and Pinlaung townships. The total estimated catchment area is about $3682 \mathrm{~km}^{2}$. Figure 1 gives the map of Myanmar with the location of the Inle Lake, its watershed and lake catchment. It is an important water body as more than 170,000 people inhabit the lake surroundings. The lake provides livelihood to the local people in term of cultivating a variety of crops in its floating islands, fisheries, gold and silver smithies, cotton weaving, black smithy, trade and transportation, and source of electricity. The lake also provides the habitat to large varieties of migrating waterfowls and other birds and is designated as a National Sanctuary for the birds. Due to its picturesque location and diverse fauna, unique lifestyles and traditions of human inhabitants, the lake is considered as one of the primary tourist destinations in Myanmar. Over the years, the Inle lake is suffering from environmental degradation due to increase in population resulting in increase in large numbers of human activities like: (1) the houses have been built inside the lake having poor sanitation and improper management of wastes, (2) livestock breeding as a source of garbage and sewage, (3) industries, their wastes and effluents being directly or indirectly discharged into the lake, and (4) shrinkage of open lake water area. Deforestation and intense agricultural practices in its catchment have further added silt and nutrients to the shallow lake. The dependence of the entire population on the forest for fuelwood is resulting in heavy deforestation. The fertilizers and pesticides from the floating gardens and sewage from the catchment are also reaching the lake in addition to sediments and nutrient causing the lake eutrophic, a trophic state which is indicative of the deteriorated state of lake health.

Literature has shown no work on the Inle Lake. Further, the data related to water quality, meteorology, sewage generation/treatment, and any conservation activity being undertaken is not available. Public awareness as well as public participation for lake management is practically nil. The present work is devoted to the preparation of a conservation plan for managing the lake environmentally so that the benefits from the conserved lake may be extended to the people inhabiting the lake and its surroundings.

\section{Identification of Lake Problems}

The Inle Lake, both natural and man-made, is in different stages of degradation due to anthropogenic activities being carried out in and around the lake. Based on the available data and subsequent analysis, Table 1 depicts the major problems identified in 1990 and 2010, and a comparison of the different problems indicates that there is continuous degradation of the lake necessitating conservation activities to be implemented immediately so that its health is not further jeopardized.

Table 1 below shows that population growth coupled with sewage, solid waste generation and deforestation, poor sanitation and improper management of wastes, livestock breeding and industrial effluents have serious impacts on the lake water quality resulting in deterioration of human health, fish species, recreational use and, ultimately, lake eutrophication. Water quality monitoring is the most important indicator for assessing the lake health as well as for monitoring the impact of restoration on the lake health. The water quality of the Inle Lake was assessed with respect to the management of $\mathrm{pH}$, Temperature, Turbidity, Total Dissolved Solids, Total Hardness, Chloride, Alkalinity, Ammonia, DO, $\mathrm{PO}_{4}-\mathrm{P}, \mathrm{NO}_{3}{ }^{-}-\mathrm{N}$ and $\mathrm{NO}_{2}{ }^{-}-\mathrm{N}$ from nine sampling locations in January 2012. The Trophic Stage Index (TSI) of the Inle Lake was also determined by using the Carlson Trophic State Index (CTSI) method as studied by Tim Loftus, Jane Frankenberger and Laura Esman (2012), and the results are given in Table 2. TP (total phosphorus) was used for determining the Carlson Trophic State Index 
in 2004, taken as a base line data, which was used by Akaishi and Satake et al 2006, for comparing the TP of 2012 as shown in Table 2 .

Table 2 shows that in-lake activities have a serious impact on the trophic state of the lake as compared to outside-lake activities. The water quality of the lake is also not fit for drinking while some floating villages use the water for domestic purposes impacting the health of the population.

The Nampam market area is highly eutrophic due to man-made activities. The Naung Shwe tourist hub, Paung Taw Oo pagoda and silver smithy area are nearly eutrophic due to domestic sewage, improper management of solid waste and poor sanitation from the inside and surrounding villages. The floating villages, floating gardens and tourists have more impact than outside lake activities on the lake catchment.

\begin{tabular}{|c|l|c|c|l|}
\hline S.No. & \multicolumn{1}{|c|}{ Problem of Lake } & $\mathbf{1 9 9 0}$ & $\mathbf{2 0 1 0}$ & \multicolumn{1}{|c|}{ Increase } \\
\hline 1 & Population growth (million) & 0.53 & 0.59 & $1.02 \%$ \\
\hline 2 & Sewage Generation (MLD) & 58 & 64 & No treatment facility available \\
\hline 3 & Solid waste Generation (MT) & 192 & 212 & No management facility available \\
\hline 4 & $\begin{array}{l}\text { Sanitation facility (\% of the } \\
\text { population) }\end{array}$ & 20 & 50 & Facilities are Partially available \\
\hline 5 & $\begin{array}{l}\text { Shrinkage of open water area } \\
\left(\mathrm{km}^{2}\right)\end{array}$ & 68 & 53 & $22 \%$ loss of area \\
\hline 6 & $\begin{array}{l}\text { Deforestation (close forest } \\
\left.\text { and open forest) (km }{ }^{2}\right)\end{array}$ & 2058 & 1418 & $31 \%$ loss of forest \\
\hline 7 & Agriculture land (km²) & 574 & 1604 & $180 \%$ increase in agriculture land \\
\hline 8 & $\begin{array}{l}\text { Settlement area (inside the } \\
\text { Lake) }\left(\mathrm{km}^{2}\right)\end{array}$ & 310 & 318 & $2.6 \%$ increase \\
\hline
\end{tabular}

Table 1. Problems of the Inle Lake and its Catchment.

\begin{tabular}{|c|c|c|c|c|}
\hline \multirow[b]{2}{*}{ S.No. } & \multirow[b]{2}{*}{ Name of Location } & \multicolumn{2}{|c|}{ Carlson Trophic State Index (CTSI) } & \multirow{2}{*}{$\begin{array}{c}\text { Lake Sta- } \\
\text { tus }\end{array}$} \\
\hline & & $\begin{array}{l}\mathrm{TP} \mu \mathrm{g} / \mathrm{I} \\
(2004)\end{array}$ & TP $\mu g / I(2012)$ & \\
\hline 1 & $\begin{array}{l}\text { Near the inflow of Paungpain } \\
\text { stream }\end{array}$ & (2004) & $\mathrm{TP} \mu \mathrm{g} / \mathrm{l}$ & Oligotrophic \\
\hline 2 & Naung Shwe tourist hub & (2012) & 43 & Mesotrophic \\
\hline 3 & Near hotel zone area & - & - & \\
\hline 4 & Upstream of Nanpan Stream & 5.2 & 8.22 & Oligotrophic \\
\hline 5 & Floating garden area & - & - & \\
\hline 6 & Open water area & 3.5 & 7.27 & Oligotrophic \\
\hline 7 & Paung Taw Oo Pagoda & 2.4 & 12.33 & Mesotrophic \\
\hline 8 & Nanpam market & 5.7 & 69.26 & Eutrophic \\
\hline 9 & Sliver smith area & 6.9 & 41.11 & Mesotrophic \\
\hline
\end{tabular}

Table 2. Evaluation of CTSI of Inle Lake.

\begin{tabular}{|c|l|c|l|}
\hline S.No. & \multicolumn{1}{|c|}{ Activity } & $\begin{array}{c}\text { Budget } \\
\text { Million US\$ }\end{array}$ & Lake Status \\
\hline 1 & $\begin{array}{l}\text { Dams, weirs, dredging, deweeding, old floating } \\
\text { garden, fencing, surveying }\end{array}$ & 325 & $\begin{array}{l}\text { Irrigation } \\
\text { Department } \\
\text { and Forest } \\
\text { Department }\end{array}$ \\
\hline 2 & $\begin{array}{l}\text { Establishment of Forest Reserve, Natural } \\
\text { Forest Management, Community Forest, Forest } \\
\text { Plantation, Agro forestry, Contour bund, Terrace, } \\
\text { Protection wildlife }\end{array}$ & Total & $\mathbf{3 2 5}$ million US\$ \\
\hline
\end{tabular}

Table 3. Conservation being Undertaken for the Inle Lake and its Catchment (1992-2011).
Conservation and Management of the Inle Lake

As indicated earlier, since 1992, the Myanmar government has been undertaking the conservation of the Inle Lake through a Conservation Committee consisting of seven Departments as studied by $\mathrm{Su}$ and Jassby (2000). A total of 325 million US $\$$ has been made available for taking up the conservation activities. Table 3 gives the details of the cost of conservation activities undertaken by the Myanmar government. Based on the above data, a conservation and management plan for the conservation of the Inle Lake has been proposed and is presented in Table 4.

The proposed conservation and management plan of the Inle Lake is for three years and is proposed in addition to the budget already allocated by the Government.

Monitoring is very important for lake conservation such as water quality monitoring which is used as the indicator of lake health and is important for the assessment of lake diagnosis. Most of diagnoses of the lake are directly related with the water quality. The water quality monitoring of lake's water should be done weekly. By monitoring the various aspects, a conservation plan can implemented easily and more effectively.

\section{Conclusions}

The Inle Lake is faced with combined threats from natural and anthropogenic activities causing reduction in lake storage capacity, deterioration of water quality, effect on navigability, decline in livestock and other products. Based on field data, problems are identified with particular reference to the deteriorated water quality. The main problems of the Inle Lake in many place is its eutrophic state (station 2, 7 and 9) and some places suffer from mass eutrophication (station 8) due to anthropogenic activities. By the conservation and management of the Inle Lake and its catchment, water quality will improve, which will positively affect the domestic water supply for the floating villages and eutrophication of the lake will reduce. Tourism will be more blooming in this area due to improvement in the living standard of local the people.

\section{Acknowledgments}

In this article, author Zaw Lwin is thankful to the Indian Technical and Economic Cooperation (ITEC) programme, Government of India for sponsoring this M.Tech degree program. 


\begin{tabular}{|c|c|c|c|c|c|c|c|}
\hline \multirow{2}{*}{$\begin{array}{l}\text { S. } \\
\text { No. }\end{array}$} & \multirow[b]{2}{*}{ Problem } & \multirow{2}{*}{$\begin{array}{l}\text { Activities Proposed } \\
\text { Plan }\end{array}$} & \multicolumn{4}{|c|}{ Management Plan (Million US\$) } & \multirow[b]{2}{*}{ Remark } \\
\hline & & & $\begin{array}{l}\text { Capital } \\
\text { Cost }\end{array}$ & $\begin{array}{l}\text { Man } \\
\text { Power }\end{array}$ & $\begin{array}{c}\text { O \& M } \\
\text { Cost }\end{array}$ & $\begin{array}{l}\text { Total } \\
\text { Cost }\end{array}$ & \\
\hline \multirow[t]{2}{*}{1} & \multirow[t]{2}{*}{ Eutrophication } & Deweeding & 0.55 & 0.30 & 0.15 & 1.0 & $\begin{array}{l}\text { Using available } \\
\text { Machines }\end{array}$ \\
\hline & & $\begin{array}{l}\text { Dredging for removal of } \\
\text { nutrient silts }\end{array}$ & 3.3 & 0.45 & 0.66 & 4.41 & $\begin{array}{l}\text { Using available } \\
\text { Machines }\end{array}$ \\
\hline 2 & Navigation & $\begin{array}{l}\text { Dredging for } \\
\text { transportation }\end{array}$ & 2.6 & - & 0.05 & 2.65 & For 3 years \\
\hline 3 & Sewage & $\begin{array}{l}\text { Biofilter Septic Tank, } \\
\text { Ground pit holes, Waste } \\
\text { Stabilization Ponds }\end{array}$ & 9.0 & 1.2 & 0.14 & 10.34 & $\begin{array}{l}\text { In the lake } \\
\text { Catchment }\end{array}$ \\
\hline 4 & Sanitation & $\begin{array}{l}\text { Biofilter Septic Tank, } \\
\text { Twin Pit Latrine, } \\
\text { Community Toilet } \\
\text { Complex }\end{array}$ & 1.5 & 0.7 & 0.02 & 2.22 & Around the Lake \\
\hline 5 & Solid Waste & $\begin{array}{l}\text { Plastic Trash Bucket, } \\
\text { Trash Tank }\end{array}$ & 0.5 & 0.7 & 0.028 & 1.228 & Around the Lake \\
\hline 6 & $\begin{array}{l}\text { Inorganic } \\
\text { Fertilizers and } \\
\text { Pesticides }\end{array}$ & $\begin{array}{l}\text { Substitution of Organic } \\
\text { Fertilizers and Pesticides }\end{array}$ & 1.33 & - & - & 1.33 & $\begin{array}{l}\text { For Tomato } \\
\text { Floating Garden } \\
\text { for } 3 \text { years }\end{array}$ \\
\hline 7 & $\begin{array}{l}\text { Old Floating } \\
\text { Garden }\end{array}$ & $\begin{array}{l}\text { Destroying of old } \\
\text { garden }\end{array}$ & 0.2 & 0.01 & 0.002 & 0.212 & $\begin{array}{l}\text { Using available } \\
\text { Machine }\end{array}$ \\
\hline 8 & Climate Data & $\begin{array}{l}\text { Setting up of } \\
\text { Meteorology Station }\end{array}$ & 0.07 & 0.07 & 0.001 & 0.15 & $\begin{array}{l}\text { Available in } \\
\text { Naung Shwe } \\
\text { Town }\end{array}$ \\
\hline 9 & $\begin{array}{l}\text { Land use } \\
\text { Changes }\end{array}$ & $\begin{array}{l}\text { Surveying, Afforestation, } \\
\text { Protection of Soil } \\
\text { erosion, Maintaince } \\
\text { of Forest, Agriculture } \\
\text { techniques }\end{array}$ & 1.67 & - & 0.03 & 1.7 & $\begin{array}{l}\text { In the lake } \\
\text { Catchment }\end{array}$ \\
\hline \multirow[t]{2}{*}{10} & \multirow[t]{2}{*}{$\begin{array}{l}\text { Public } \\
\text { Awareness and } \\
\text { Participation }\end{array}$} & $\begin{array}{l}\text { Environmental } \\
\text { Education Show Room }\end{array}$ & 0.03 & 0.07 & 0.002 & 0.12 & $\begin{array}{l}\text { Available in } \\
\text { Naung Shwe } \\
\text { Town }\end{array}$ \\
\hline & & $\begin{array}{l}\text { Public awareness \& } \\
\text { participation plan }\end{array}$ & 1.15 & - & 0.02 & 1.17 & $\begin{array}{l}\text { For the } \\
\text { Catchment }\end{array}$ \\
\hline 11 & $\begin{array}{l}\text { Water Quality } \\
\text { Monitoring }\end{array}$ & $\begin{array}{l}\text { Construction of } \\
\text { Monitoring Unit and } \\
\text { Monitoring plan }\end{array}$ & 0.05 & 0.13 & 0.17 & 0.35 & $\begin{array}{l}\text { Available in } \\
\text { Naung Shwe } \\
\text { Town }\end{array}$ \\
\hline 12 & Vehicles & $\begin{array}{l}\text { For Environment } \\
\text { Management of Inle } \\
\text { Lake }\end{array}$ & 4.3 & - & - & 4.3 & For All \\
\hline & & Total & 26.25 & 3.63 & 1.273 & 31.18 & \\
\hline
\end{tabular}

Inle Lake in Myanmar. Corresponding address: zawlwinoo7@ gmail.com

\section{References}

Akaishi, F., Satake, M., Otaki, M., and Tominaga, N., 2006, Surface water quality and information about the environment surrounding Inle Lake in Myanmar, Japanese Society of Limnology, vol.7, 57-62.

Cooke, G.D., Welch, E.B., Peterson, S.A. and Nichols, S.A., 2005, Restoration and Management of Lakes and Reservoirs", 3rd edition, CRC presses, Taylor and Francis Group, New York.

Jane Frankenberger and Laura Esman , 2012, Monitoring Water in Indiana, pp. 101.

Ministry of Environment and Forests (NRCD), 2010, conservation and Management of Lakes- an Indian Perspective, Government of

Table 4. Conservation Plan for Environmental Management of Inle Lake.

M.P. Sharma, Ph.D. has been working as Associate Professor at the Alternate Hydro Energy Center, Indian Institute of Technology, Roorkee (India), since the last 25 years. His area of research are renewable energy with special reference to bio-diesel production and utilization, Modeling of IRES, Hybrid Energy Systems, induction generators, EIA of renewable energy projects, Energy and Environment conservation, conservation of water bodies, water quality assessment and $G H G$ emissions from reservoirs and lakes.

Corresponding address: mpshafah@iitr.ernet.in

Zaw Lwin is pursuing his Masters of Technology Degree in "Environmental Management of Rivers and Lakes" with focus on Environmental Management of the
India, New Delhi, $<<$ http://moef.nic.in/modules/ recent-initiatives/nlcp/Lake_Conserv-Manage_ India.pdf $>>$, (accessed on 2 April 2012).

Sharma, M.P., Kumar, A. and Rajvanshi, S., 2010, Assessment of Trophic State of Lakes: A Case of Mansi Ganga Lake in India, Hydro Nepal vol.6, pp. 65-72.

Su, M. and Jassby, A.D., 2000, Inle: A large Myanmar lake in transition, Lakes \& Reservoirs: Research and Management, vol.5, Issue 1, pp. 49-54.

Tim Loftus, How Do I Get That Pretty Blue Color?, Phosphorus (2nd of 2 articles), http:// www.lagoonsonline.com/laboratory-articles / phosphorous-2.htm, (accessed on 3 June 2012). 